\title{
THE ANTICIPATORY REASONABLE ADJUSTMENT DUTY: REMOVING THE BLOCKAGES?
}

\author{
ANNA LAWSON* AND MaRia ORChARD**
}

\begin{abstract}
The anticipatory reasonable adjustment duty, introduced by the Disability Discrimination Act 1995 and now found in the Equality Act 2010, has been hailed as an innovative and proactive tool for embedding disability equality in services and public functions. Despite important successes, the duty has had a surprisingly low profile in academic scholarship and has struggled to fulfil its practical potential. We seek to understand how this has happened, identifying a range of factors that may operate as blockages to the success of the duty. Whilst these factors are interrelated, we group them under three main headings - visibility, uncertainty and enforcement. We reflect critically on whether, and if so how, relevant blockages can be tackled to enable the duty to embed disability equality more effectively within services and public functions and whether new supplementary measures (particularly concerning accessibility) are also needed.
\end{abstract}

KEYWORDS: disability, anticipatory reasonable adjustment, discrimination, equality and inclusion, accessibility, services and public functions, access to justice, Equality Act 2010.

\section{INTRODUCTION}

The anticipatory reasonable adjustment duty in the Equality Act 2010 (EqA) requires providers of services and public functions continually to identify any possible disability-related disadvantage, and to take reasonable steps to avoid or remove it - failure to do so constituting unlawful discrimination. It has been described, by key figures in the former Disability Rights Commission (DRC), as "immensely significant" and "a major driver in encouraging service providers to think in advance about removing barriers experienced by disabled customers or potential customers". ${ }^{1}$ A Danish

* Professor of Law and Principal Investigator for the Inclusive Public Space research project, University of Leeds. Address for Correspondence: School of Law, The Liberty Building, University of Leeds, Leeds, LS2 9JT, UK. Email: A.M.M.Lawson@leeds.ac.uk.

** Postdoctoral Research Fellow, Postdoctoral Research Fellow on the Inclusive Public Space research project, University of Leeds. This article has been written as part of the Inclusive Public Space project, funded by the European Research Council under the European Union's Horizon 2020 research and innovation programme (grant agreement no 787258).

${ }^{1}$ C. Gooding and C. Casserley, "Open for All? Disability Discrimination Laws in Europe Relating to Goods and Services" in A. Lawson and C. Gooding (eds.), Disability Rights in Europe: From Theory to Practice (Oxford 2005), 135, s. 4.2. 
scholar, after scrutinising both the EqA's duty and the analogous duty in Norway, ${ }^{2}$ has hailed the former as a particularly promising example of such duties. ${ }^{3}$ It has also provided inspiration for similar (although ultimately unsuccessful) legislative initiatives at the EU level. ${ }^{4}$

Over the years, the anticipatory reasonable adjustment duty has provided the basis for a number of high-profile cases, with far-reaching implications for duty-bearers. In relation to public functions, for example, it was held in ZH v Commissioner of the Metropolitan Police ${ }^{5}$ that the duty was breached by the failure of officers to adjust their standard procedures when interacting with an autistic person. Roads $v$ Central Trains ${ }^{6}$ and Royal Bank of Scotland $v$ Allen $^{7}$ provide examples of services cases in which failures to adjust exclusionary physical and structural features were found to contravene the duty. In First Group $v$ Paulley, ${ }^{8}$ the Supreme Court held that a bus company had breached the duty by failing to put in place systems that made it sufficiently clear that wheelchair users should have priority access to designated wheelchair accessible spaces. The duty is currently being used to mount a case involving several hundred claims based on failures by supermarkets to embed adequately disability equality in their service delivery during the first Covid-19 lockdown period. ${ }^{9}$

Despite these successes, the duty is struggling to achieve its aims. In 2017, the Equality and Human Rights Commission (EHRC) reported that disabled people continue to experience significant barriers to accessing services and public functions ${ }^{10}$ - a problem worsened by the Covid-19 crisis. ${ }^{11}$ Two parliamentary committees have drawn attention to wide-scale implementation failures, identifying lack of awareness and understanding

2 Act of 6 June 2006 No. 42 relating to a prohibition against discrimination on the basis of disability, as amended by Act of 21 June 2013 No. 61 (the Anti-Discrimination and Accessibility Act), ch. 3 .

${ }^{3}$ M. Liisberg, "Accessibility of Services and Discrimination: Concentricity, Consequence and the Concept of Anticipatory Reasonable Adjustment" (2015) 15 International Journal of Discrimination and the Law 123.

4 See e.g. the European Commission's Proposal for a Directive on Implementing the Principle of Equal Treatment Between Persons Irrespective of Religion or Belief, Disability, Age or Sexual Orientation $(\mathrm{COM} / 2008 / 426 \mathrm{final})$, Article 4, which reads "access to and supply of goods and services which are available to the public, including housing, shall be provided by anticipation".

5 [2012] EWHC 604 (Q.B.), [2012] Eq.L.R. 425.

6 [2004] EWCA Civ 1541, (2005) 21 Const.L.J. 456.

7 [2009] EWCA Civ 1213, (2010) 112 B.M.L.R. 30.

8 [2017] UKSC 4, [2017] 1 W.L.R. 423.

9 J. Pring, "Coronavirus: Supermarkets Face 'Biggest Class Action of Its Kind' Over Discrimination Claims", Disability News Service, available at https://www.disabilitynewsservice.com/coronavirussupermarkets-face-biggest-class-action-of-its-kind-over-discrimination-claims/\#: :text=More $\% 20$ than $\%$ $20200 \% 20$ disabled\%20people,legal\%20case $\% 20$ of\%20its\%20kind (last accessed 7 April 2021).

10 EHRC, "Being Disabled in Britain: A Journey Less Equal" (2017), available at https://www.equalityhumanrights.com/en/publication-download/being-disabled-britain-journey-less-equal (last accessed 7 April 2021), especially ch. 8.2.

${ }^{11}$ House of Commons Women and Equalities Committee, "Unequal Impact? Coronavirus, Disability and Access to Services" (2020) HC 1050, available at https://committees.parliament.uk/publications/4068/ documents/40461/default/ (last accessed 7 April 2021). 
of the duty's existence and requirements as a major cause of the problem. ${ }^{12}$ According to the House of Lords Select Committee on the Equality Act 2010 and Disability (hereafter, "the House of Lords Committee"), "witness after witness told us that ... the provisions were neither well known nor well understood"13 either by disabled people in whose favour they should be operating or by duty-bearers who should be implementing them. It noted particular problems relating to service providers' limited knowledge of the existence of the anticipatory reasonable adjustment duty. ${ }^{14}$ Similar limitations in the awareness of those discharging public functions (relating to planning) were also recognised as hindering EqA compliance by the House of Commons Women and Equalities Committee. ${ }^{15}$ Another problem is the failure of many duty-bearers to grasp that reasonable adjustment duties impose binding legal obligations, tending instead to view them as "favouritism" or the provision of "special treatment" or "perks". ${ }^{16}$

Interestingly, despite drawing attention to the importance of the anticipatory duty in its 2017 report on disability and the built environment, the Women and Equalities Committee is itself guilty of overlooking it in subsequent work. In its 2019 report on enforcing the EqA, the Committee asserts that there are currently only two "sets of equality-related duties that require a proactive approach" - the public sector equality duty (PSED) and the gender pay gap regulations. ${ }^{17}$ The omission of the anticipatory reasonable adjustment duty from this list sounds loud alarm bells about the thickness of the folds of obscurity in which the duty is currently cloaked.

In academic literature too, although there are examples of relevant scholarship, ${ }^{18}$ the profile of the duty has been surprisingly low. For example, it is not mentioned at all in McColgan's multi-jurisdictional monograph on equality law (including the EqA), ${ }^{19}$ and, while acknowledged in Hepple's

12 House of Lords Select Committee on the Equality Act 2010 and Disability, "The Equality Act 2010: The Impact on Disabled People" (2016) HL Paper 117, available at https://publications.parliament. uk/pa/ld201516/ldselect/ldeqact/117/117.pdf (last accessed 7 April 2021); and House of Commons Women and Equalities Committee, "Building for Equality: Disability and the Built Environment" (2017) HC 631, available at https://publications.parliament.uk/pa/cm201617/cmselect/cmwomeq/631/ 631.pdf (last accessed 7 April 2021).

13 House of Lords Committee, "The Equality Act 2010", at [201].

14 Ibid., at [202]-[208].

15 See e.g. Women and Equalities Committee, "Building for Equality", [63], [69].

${ }_{17}$ House of Lords Committee, "The Equality Act 2010", [206]-[207].

17 House of Commons Women and Equalities Committee, "Enforcing the Equality Act 2010: The Role of Law and the Equality and Human Rights Commission" (2019) HC 1470, available at https://publications. parliament.uk/pa/cm201719/cmselect/cmwomeq/1470/1470.pdf (last accessed 7 April 2021), [138].

18 For analysis of this duty prior to the EqA, see e.g. A. Lawson, Disability and Equality Law in Britain: The Role of Reasonable Adjustment (Oxford 2008). For post EqA analysis, see e.g. Liisberg, "Accessibility of Services and Discrimination"; A. Pearson, "What's Worth Got to Do with It? Language and the Socio-legal Advancement of Disability Rights and Equality" (2014) 20(3) Web Journal of Current Legal Issues, available at http://webjcli.org/index.php/webjcli/article/view/352 (last accessed 7 April 2021); and A. Pearson, "The Debate about Wheelchair Spaces on Buses goes Round and Round: Access to Public Transport for People with Disabilities as a Human Right" (2018) 69 Northern Ireland Legal Quarterly 1. Other publications, focusing on the implementation of the anticipatory duty in specific sectors, will be mentioned where relevant in the discussion below.

19 A. McColgan, Discrimination, Equality and the Law (Oxford 2014). 
monograph on the EqA, it features only on two pages ${ }^{20}$ and is not mentioned at all in the broader discussions of proactive duties. ${ }^{21}$ The reactive or responsive reasonable adjustment duty is by no means well known or implemented, but its profile is significantly higher than that of its anticipatory sibling. ${ }^{22}$

In this article, we draw attention to problems which the anticipatory reasonable adjustment duty has encountered and reflect critically on how they might be addressed so as to give the duty a stronger chance of fulfilling its aim of embedding disability equality in services and public functions. Academic literature will be referred to where relevant but, given the surprisingly small amount of such scholarship, we will also draw extensively on parliamentary enquiries ${ }^{23}$ - which provide rich sources of data about the operation of the duty in practice as well as suggestions for reform.

The article is divided into five main parts. The first of these provides context for the subsequent analysis by explaining the duty's origins, the legislative provisions on which it is based, and its relationship with other obligations in the EqA and the UN Convention on the Rights of Persons with Disabilities (CRPD). ${ }^{24}$ The following three parts each identify and reflect on different types of problems or blockages to success - visibility, uncertainty and enforcement respectively. We conclude that reform is needed if disability inclusion is to be effectively embedded in services and public functions and argue that, as well as measures focusing on the duty itself, such reform will also need to address the operation and enforcement of the EqA more generally and to introduce new supplementary accessibility regulations.

\section{SituAting The DutY}

\section{A. Historical Origins}

The anticipatory reasonable adjustment duty, now in the EqA, dates back to interpretations in codes of practice of the Disability Discrimination Act

20 B. Hepple, Equality: The Legal Framework, 2nd ed. (Oxford 2014), 96-97.

21 Ibid., ch. 6 and 220-24.

22 See further S. Bunbury, "The Employer's Duty to Make Reasonable Adjustments. When Is a Reasonable Adjustment, Not Reasonable?" (2009) 10 International Journal of Discrimination and the Law 111; A. Lawson, "Disability and Employment in the Equality Act 2010: Opportunities Seized, Lost and Generated" (2011) 40 Industrial Law Journal 359 - although the anticipatory duty also features here; D. Foster and V. Wass, "Disability in the Labour Market: An Exploration of Concepts of the Ideal Worker and Organisational Fit that Disadvantage Employees with Impairments" (2013) 47 Sociology 705; R. Harwood, “The Dying of the Light': The Impact of the Spending Cuts, and Cuts to Employment Law Protections, on Disability Adjustments in British Local Authorities" (2014) 29 Disability and Society 1511; M. Bell, "Mental Health at Work and the Duty to Make Reasonable Adjustments" (2015) 44 Industrial Law Journal 194; R. Crasnow and S. Fraser-Butlin, "Disabled Compared to Whom? An Analysis of the Current Jurisprudence on the Appropriate Comparator under the UK Equality Act's Reasonable Adjustment Duty" (2015) 15 Equal Rights Review 75; and R. Harwood, "What Has Limited the Impact of UK Disability Equality Law on Social Justice?" (2016) 5(4) Laws, available at https://www.mdpi.com/2075-471X/5/4/42 (last accessed 7 April 2021).

23 House of Lords Committee, "The Equality Act 2010"; Women and Equalities Committee, "Building for Equality"; Women and Equalities Committee, "Enforcing the Equality Act 2010".

242515 UNTS 3 (CRPD). 
1995 (DDA) - a statute repealed and replaced by the EqA. The DDA did not explicitly mention such a duty. It did provide, however, that in services contexts the reasonable adjustment duty operated in favour of "disabled persons", in the plural, whereas in employment contexts it operated in favour of a "disabled person", in the singular. This reference to disabled persons in the plural was interpreted by the National Disability Council as indicating that the duty was owed to disabled people generally, with the result that it must arise prior to duty-bearers becoming aware of any particular disabled person being disadvantaged. ${ }^{25}$ The statutory codes of practice on services, drawn up by that Council and subsequently the DRC, stressed the "anticipatory" nature of the duty. ${ }^{26}$

In 2004 the Court of Appeal, in Roads $v$ Central Trains, ${ }^{27}$ endorsed the approach adopted in these codes of practice. The reference to "disabled persons" in the articulation of the reasonable adjustment duty in the services provisions meant that no reasonable adjustment duty would arise unless disabled persons generally would have experienced the required level of disadvantage. Roads thus affirms that some element of group disadvantage was an essential element of anticipatory reasonable adjustment claims. According to Sedley L.J., in order to establish that "disabled persons" would have been sufficiently disadvantaged, it was not necessary to show that "all or most disabled persons" would have been so affected; 28 instead, demonstrating "any significant impact on, say, wheelchair users as a class" would suffice. ${ }^{29} \mathrm{He}$ also warned against demanding detailed statistical evidence to prove disadvantage to a relevant group, urging that judges should instead rely on their own appraisal of the situation with the help of expert evidence where appropriate. ${ }^{30}$ Sedley L.J. also helpfully observed that, in assessments of the reasonableness of adjustments, regard should be had to the fact that the policy of the Act is "to provide access to a service as close as it is reasonably possible to get to the standard normally offered to the public at large". 31

25 See generally the account of these duties provided by J. White (a member of the National Disability Council) in "DDA: Service Providers' Duty to Make Reasonable Adjustments" (1999) 88 Equal Opportunities Review 33.

26 Department for Education and Employment, DDA 1995 Code of Practice, Rights of Access: Goods, Facilities, Services and Premises 1999, [4.7]; DRC, DDA 1995 Code of Practice, Rights of Access. Goods, Facilities, Services and Premises 2002, [4.14]; and DRC, DDA 1995 Code of Practice, Rights of Access: Services to the Public, Public Authority Functions, Private Clubs and Premises 2006, [6.16]. For discussion of the duty by people involved in drafting these codes, see White, "DDA"; and Gooding and Casserley, "Open for All?", 152-54.

27 [2012] EWHC 604 (Q.B.).

28 Ibid., at [26].

29 Ibid.

30 Ibid.

31 Ibid., quoting from Mynors Ch. in Re Holy Cross, Pershore [2001] 3 W.L.R. 1521, at [105] (Worcester Consistory Court). 


\section{B. Current Statutory Underpinnings}

The anticipatory reasonable adjustment duty continued into the EqA with the benefit of a number of improvements not significantly affecting its substance. It is now rooted in sections 20-22 of the EqA, read together with schedules 2 and $3 .{ }^{32}$ Before explaining these provisions more fully, it should be noted that section 29(7) places the duty on providers of services and public functions and that sections 20-22 apply to what may be termed the "reactive" or "responsive" reasonable adjustment duty as well as its anticipatory sibling. This reactive duty, applicable to employment and premises cases, arises only when a potential duty-bearer knows or ought to know that a particular disabled person is placed at a substantial disadvantage within the meaning of section 20(3)-(5).

Paragraphs (3)-(5) of section 20, which require duty-bearers to take reasonable steps to tackle relevant types of disadvantage, refer to a disabled person in the singular being placed at a substantial disadvantage. This emphasis on a particular disabled person is a key feature of the reactive reasonable adjustment duty but inconsistent with an anticipatory approach. Schedule 2 of the EqA provides that, in services and public functions cases, the term "disabled person" in section 20(3)-(5) should be read instead as "disabled persons generally". ${ }^{33}$ It is through this conversion of phrases in section 20(3)-(5), from the singular to the plural, that the EqA unleashes the anticipatory dimension of its reasonable adjustment duties in contexts of services and public functions. Importantly, however, the reference in section 21 to a disabled person in the singular remains unchanged. This specifies that breach of the reasonable adjustment duty constitutes discrimination against a disabled person only if the duty-bearer "fails to comply with that duty in relation to that person". Accordingly, although the anticipatory reasonable adjustment duty arises regardless of whether or not a particular individual is placed at a substantial disadvantage, breach of it will constitute unlawful discrimination only if a particular disabled person can show that the breach caused them substantial disadvantage.

Besides giving the duty its anticipatory nature, Schedule 2, together with Schedule 3, shapes the character and scope of the anticipatory reasonable adjustment duty in various other ways. For instance, steps which would fundamentally alter the nature of a service or be beyond the power of those exercising a public function will never be "reasonable"; 34 and

\footnotetext{
32 Note that, although education is a type of service (in relation to which the anticipatory duty operates), it is dealt with separately in Schedule 13.

33 Schedule 2, s. 2(2).

34 Schedule 2, s. 2(7)-(8).
} 
exemptions are introduced for transport vehicles (particularly in relation to physical features), ${ }^{35}$ legislation, and parliamentary and judicial functions. ${ }^{36}$

As already mentioned, authoritative guidance on the duty is set out in statutory codes of practice - the current version of which is compiled by the EHRC. ${ }^{37}$ This articulates in plain language key implications of the complex legislative framework outlined above. It stresses that the duty is "owed to disabled people generally", ${ }^{38}$ which means "it applies regardless of whether the service provider knows that a particular person is disabled or whether it currently has disabled customers". 39 The duty requires "consideration of, and action in relation to, barriers that impede people with one or more kinds of disability prior to an individual disabled person seeking to use the service or ... function". ${ }^{40}$ The Code explains that the duty is a "continuing" and "evolving" one, demanding that duty-bearers keep "the ways they are meeting the duty under regular review" rather than treating it as "something that needs simply to be considered once only, and then forgotten". ${ }^{41}$ As explained in Section IV(A) below, the Code also provides guidance as to what is meant by "reasonable" for purposes of the duty. This guidance is particularly important given that the EqA contains no such guidance and that the notion of reasonableness in this context covers both the effectiveness of the steps taken (in removing the disadvantage) and issues relating to disproportionate or undue burden.

\section{Relationship Between the Anticipatory Reasonable Adjustment Duty and Other Equality Act Obligations}

The relationship between the anticipatory reasonable adjustment duty and related EqA obligations is an important and complex issue demanding more space than is available in an article such as this with a different principal focus. It has been addressed more fully by Lawson in work which, although pre-dating the $\mathrm{EqA},{ }^{42}$ remains relevant today and on which we draw to provide context for readers less familiar with the anticipatory duty than other parts of UK equality law.

35 Schedule 2, s. 3.

${ }^{36}$ Schedule 3, ss. 2, 1 and 3, respectively.

37 EHRC, "Equality Act 2010 Code of Practice: Services, Public Functions and Associations. Statutory Code of Practice" (2011), available at https://www.equalityhumanrights.com/sites/default/files/servicescode_0.pdf (last accessed 7 April 2021), particularly ch. 7.

${ }^{38}$ Ibid., at [7.19].

39 Ibid., at [7.22]

${ }^{40}$ Ibid., at [7.20]; see also [7.24]-[7.25].

${ }^{41}$ Ibid., at [7.27]

42 See Lawson, Disability and Equality Law in Britain, chs. 3.2.1-3.2.4 and 3.3.1-3.3.4 for comparison of reactive and anticipatory reasonable adjustment duties; ch. 4.2.2 for comparison of the anticipatory reasonable adjustment duty with indirect discrimination; and ch. 5.5.1 for comparison between the anticipatory duty and the Disability Equality Duty (the predecessor of the Public Sector Equality Duty in the disability context). 
The EqA's reasonable adjustment duties, if breached, result in freestanding liability for discrimination, distinct from direct or indirect discrimination, for example. These reasonable adjustment duties are anticipatory in contexts of services and public functions but reactive in contexts of employment and housing. No distinction is made between these two types of reasonable adjustment duties outside the schedules of the Act and both require duty-bearers to take reasonable steps to prevent disability-related substantial disadvantage. Nevertheless, there are significant differences. Most notably, the reactive duty is triggered only when a duty-bearer knows or ought to know that a particular disabled person is encountering (or likely to encounter) a substantial disadvantage, whereas the anticipatory duty arises whenever a duty-bearer ought to anticipate that broad groups of disabled people might encounter such a disadvantage.

The anticipatory reasonable adjustment duty does much of the same work as indirect discrimination - a form of obligation not applicable to disability in services and public functions cases prior to the EqA. Both include an element of group disadvantage, although enforcement is by individuals adversely affected by breach. The anticipatory duty, however, is more overtly proactive and solution-oriented and is free of the statistical complexity which has historically bedevilled indirect discrimination law.

Finally, there are important points of connection between the anticipatory reasonable adjustment duty and the Public Sector Equality Duty (PSED). Both impose proactive obligations on duty-bearers to attend to disability-related disadvantage associated with their policies and operations. Unlike the former, however, the PSED applies only to public bodies and thus does not extend to the private sector. Furthermore, the PSED (which does not create liability for discrimination) is a process-oriented duty, based on the need to have "due regard" to disability equality in relevant decision-making; whereas the anticipatory reasonable adjustment duty looks to outcomes.

\section{Situating the Anticipatory Reasonable Adjustment Duty Within the UN CRPD}

The UN CRPD, ratified by the UK in June 2009, requires states parties to prohibit discrimination on the basis of disability ${ }^{43}$ and defines such discrimination to include a failure to provide reasonable accommodation. ${ }^{44}$ It is clear from the definition of "reasonable accommodation" in Article 2 that it is an "ex nunc duty ... enforceable from the moment an individual with an impairment needs it in a given situation". ${ }^{45}$ It is thus akin to the EqA's reactive reasonable adjustment duty but not its anticipatory one.

\footnotetext{
43 Articles 5, 4(1)(e).

${ }^{44}$ Article 2.

45 CRPD Committee, "General Comment No. 2 (2014) - Article 9: Accessibility" (CRPD/C/GC/2, 2014), [26].
} 
Unsurprisingly, nothing like the anticipatory reasonable adjustment duty appears in the list of types of discrimination recognised in international human rights law, set out in the CRPD Committee's General Comment No $6 .{ }^{46}$ This, of course, does not mean that it is inconsistent with the CRPD. Indeed, it covers ground conventionally covered by indirect discrimination (which does feature in the list $\mathrm{t}^{47}$ ) as well as providing a potentially powerful way of harnessing equality law to ensure the accessibility of services and facilities offered to the public - as required by Article 9 of the CRPD. These accessibility obligations, like the EqA's anticipatory duty, are group-oriented and "proactive", "systemic" and "ex ante" in nature. 48 Qualified as it is by the concept of reasonableness, however, the EqA's anticipatory duty - even if widely understood and implemented - will only ever go some of the way to supporting enforcement of rights to accessibility in Article 9. ${ }^{49}$ It does not follow from the fact that it is only one of the measures needed for implementing Article 9 rights, however, that its contribution is unimportant. ${ }^{50}$ Far from it, in the UK the anticipatory reasonable adjustment duty has important work to do in contributing to the enforcement of CRPD rights and the advancement of the model of "inclusive equality" 51 on which it rests.

\section{VisibILITY PROBLEMS}

\section{A. Invisibility on the Face of the Equality Act 2010}

As will be evident from the previous section, a superficial hunt through the EqA will not unearth the anticipatory reasonable adjustment duty. It does not feature in any of the headings of sections or schedules; nor is there any explicit mention of the "anticipatory reasonable adjustment duty". For these reasons, this duty is unquestionably not visible on the face of the legislation.

This invisibility has come about despite the fact that, by the time the EqA was being debated, the anticipatory reasonable adjustment duty was well established as a form of DDA discrimination prohibition, distinct from the reactive reasonable adjustment duty. Instead of making this obvious in the crafting of the new statute, however, both types of reasonable adjustment duties are shoehorned into sections 20-22 but in language that is appropriate only to the reactive form. As explained above, the anticipatory

${ }^{46}$ CRPD Committee, "General Comment No. 6 (2018) on Equality and Non-Discrimination" (CRPD/C/ $\mathrm{GC} / 6,2018),[18]$.

47 Ibid., at [18(b)].

${ }^{48}$ Terms used ibid., at [24].

${ }^{49}$ See generally on Article 9: A. Lawson, "Article 9: Accessibility" in I. Bantekas, M. Stein and D. Amastasiou (eds.), The UN Convention on the Rights of Persons with Disabilities: A Commentary (Oxford 2018), ch. 12.

${ }^{50}$ For a contrary view, see Pearson, "What's Worth Got to Do with It?"; and "Access to Public Transport".

51 CRPD Committee, "General Comment No. 6", [8]-[11]. 
duty emerges from changes to the wording of these sections brought about by Schedule 2 . While there was clearly no deliberate attempt to hide the anticipatory duty, it is difficult to imagine how it might have been more comprehensively hidden in the EqA had this actually been the intention of the legislators. The consequent risk that the duty will be overlooked is exacerbated by the fact that the duty does not operate in relation to employment ${ }^{52}$ - the area of equality law that attracts most attention in case law and scholarship alike.

The most obvious solution to this visibility problem would be to reform the EqA so as to bring the anticipatory reasonable adjustment duty out of the shadows of the schedules and give it a place of its own, with a title, in the main body of the Act. It might also be helpful to give it a name that separates it more clearly from the reasonable adjustment duty that operates in the employment context. It is noteworthy that the US Americans with Disabilities Act 1990 terms its equivalent of this duty the "reasonable modification" duty, ${ }^{53}$ as opposed to the "reasonable accommodation" duty which operates in employment cases. ${ }^{54}$ Such possibilities, however, were not considered in the lead-up to the EqA or by the House of Lords Committee. ${ }^{55}$

\section{B. Reduced Visibility in Official Guidance}

Codes of practice - particularly those that have received parliamentary approval and thus become "statutory" 56 - have an important role to play in providing guidance and raising awareness of equality law obligations and making legal technicalities comprehensible to duty-bearers and disabled people alike. ${ }^{57}$ Indeed, as explained above, ${ }^{58}$ it was the early DDA codes of practice that originally gave shape and content to the anticipatory reasonable adjustment duty. There is some concern, however, that the visibility, quantity and emotional power of guidance on disability-specific issues such as the anticipatory reasonable adjustment duty has reduced since the DDA was replaced by the EqA, largely because codes of practice now address many issues besides disability. ${ }^{59}$

52 See Lawson, "Disability and Employment in the Equality Act 2010", 379; and Lawson, Disability and Equality Law in Britain, 126-28 and 173-76 for arguments that the EqA should have extended the duty to the employment context.

${ }^{53}$ For public authorities, 42 USC s. 12131(2); and for private entities providing public services 42 USC s. 12182(b)(2)(A)(ii). See generally P. Blanck, Disability Law and Policy (St. Paul 2020), ch. 12.2.

${ }^{54} 42$ USC s. $12112(5)(\mathrm{A})$ ).

55 House of Lords Committee, "The Equality Act 2010"; Women and Equalities Committee, "Building for Equality".

56 According to Equality Act 2006, s. 15(4), such codes “(a) shall be admissible in evidence in criminal or civil proceedings, and (b) shall be taken into account by a court or tribunal in any case in which it appears ... to be relevant".

57 See further N. O'Brien, "The UK Disability Rights Commission and Strategic Law Enforcement: Transcending the Common Law Mind" in Lawson and Gooding, Disability Rights in Europe, 259-60.

58 See notes 26-31 above and accompanying text.

59 See e.g. House of Lords Committee, "The Equality Act 2010", [158]. 
In light of such concerns, and to help increase awareness and understanding of reasonable adjustment duties, the House of Lords Committee recommended that the EHRC should depart from its general practice of issuing codes applicable to all protected characteristics and draft "a specific Code of Practice on reasonable adjustments",60 as well as industry-specific guidance. $^{61}$

The EHRC has not issued a specific statutory code on reasonable adjustments, however. This is in part because a statutory code cannot be issued without government willingness to lay it before Parliament - a willingness that, since the infancy of the EqA, has not been forthcoming. ${ }^{62}$ The EHRC, however, has published non-statutory guidance focusing specifically on this duty, albeit that it is aimed only at disabled people and not also at dutybearers. ${ }^{63}$ In addition, it has engaged in a number of tailored initiatives to advise, guide and otherwise educate duty-bearers on the anticipatory duty. ${ }^{64}$ In 2020, for example, it issued guidance to providers of retail services, including supermarkets, about carrying out their obligations to make adjustments for disabled customers in the context of Covid-19. ${ }^{65}$ The capacity of the EHRC to engage in such tailored initiatives is, however, much more limited than that of the DRC, which (together with the Commission for Racial Equality and Equal Opportunities Commission) it replaced on 1 January 2007.66 The House of Lords Committee noted in 2016 that the EHRC's budget had been reduced by 75 per cent since 2010, making its core funding for 2015-16 £17.1 million - substantially less than the DRC's budget of $£ 21.2$ million for 2006-07.67

In short, while the EHRC has issued valuable guidance on the anticipatory reasonable adjustment duty, it is more limited and less prominent than the guidance previously issued by the DRC. Any positive change seems unlikely as long as government resistance to new EqA statutory codes persists and the EHRC continues to be funded at levels that compare so unfavourably with those of the DRC.

\section{UnCERTAINTy Problems}

Here we identify and discuss two types of legal uncertainty which, we suggest, have contributed to confusion and controversy about the duty. The first concerns the inherent uncertainty in the notion of reasonableness.

\footnotetext{
${ }^{60}$ Ibid., at [231] and rec. 18.

61 Ibid., at [234] and rec. 19.

62 An approach described as "perverse" by the House of Lords Committee: ibid., at [163].

63 EHRC, Using a Service: Reasonable Adjustments for Disabled People, 2 December 2019.

64 See in particular the powers granted by Equality Act 2006, s. 13(1)(c) and (d), in connection with the duties of the EHRC to "promote awareness and understanding" of EqA rights and to "work toward the elimination of unlawful discrimination" in Equality Act 2006, s. 8(1)(d), (f).

65 See EHRC, Retailers' Legal Responsibility to Disabled Customers, 4 September 2020.

66 By virtue of the Equality Act 2006.

67 House of Lords Committee, "The Equality Act 2010", [133].
} 
While this brings with it important benefits in terms of flexibility, we argue that more should be done to limit its scope through the introduction of accessibility and other regulations. The second issue that will be addressed here is also connected with the idea of reasonableness but, because it raises distinct uncertainty problems, is given separate attention. It concerns questions about the extent to which the anticipatory duty requires duty-bearers to respond to the specific circumstances of particular disabled individuals. In other words, it concerns the extent to which the anticipatory duty imposes obligations that are reactive as well as ones that are anticipatory in nature.

\section{A. The Inherent Uncertainty of Reasonableness}

In the EqA, the divide between reasonable and unreasonable separates cases in which failure to make an adjustment results in liability for discrimination from those in which it does not. Nevertheless, determining exactly where that divide lies can be difficult. This problem is not unique to the EqA. In the US, it has been described as the "great unsettled question" 68 of the Americans with Disabilities Act 1990 - the associated uncertainty attracting concerns about conflicting expectations and understandings, risks of increased litigation and burdens for businesses. ${ }^{69}$

Uncertainty in the operation of reasonable adjustment or accommodation duties even underpins calls for their abolition. Richard Epstein, for example, argues that "the utter want of precision is ... a reason for jettisoning the system altogether". ${ }^{70}$ Admittedly, the focus of this argument is the employment context, but it seems likely that duties requiring providers of services or public functions to make reasonable adjustments would be viewed in the same way.

Conversely, the uncertainty and compromise inherent in the concept of reasonableness have also attracted criticism from proponents of the complete removal of all disabling barriers. ${ }^{71}$ Their concerns include the fact that reasonable adjustment duties accept ableist norms as their starting point and thereby legitimise them, and that questions of reasonableness (on which hang far-reaching implications for equality and inclusion) are left to be decided by judges who may have very little familiarity with

${ }^{68}$ P.S. Karlen and G. Rutherglen, "Disabilities, Discrimination, and Reasonable Accommodation" (1996) 46 Duke Law Journal 1, 8.

${ }^{69}$ See e.g. C.L. Weaver, "Incentives Versus Controls in Federal Disability Policy" in C.L. Weaver (ed.), Disability and Work: Incentives, Rights and Opportunities (Lanham and London 1991), 9-11; S.B. Epstein, "In Search of a Bright Line: Determining when an Employer's Hardship Becomes 'Undue' under the Americans with Disabilities Act" (1995) 48 Vanderbilt Law Review 391; and R. Epstein, Forbidden Grounds: The Case Against Employment Discrimination Laws (Cambridge 1992), 489-91.

${ }^{70}$ Epstein, Forbidden Grounds, at 489-90.

71 See e.g. S. Prideaux, Good Practice for Providing Reasonable Access to the Physical Built Environment for Disabled People (Leeds 2006), 38-39. 
disability. ${ }^{72}$ Pearson has therefore argued that the anticipatory reasonable adjustment duty should be abandoned and replaced by an entitlement to "rightful access", without any "reasonableness" or "undue burden" limitation. ${ }^{73}$

The uncertainty associated with "reasonableness", however, is a corollary of the flexibility that allows reasonable adjustment duties to respond to the particular circumstances of each individual case. This flexibility, at least in reasonable adjustment duties with a reactive dimension, allows account to be taken of the variation in impairments and the types of measures needed to remove the disadvantage that a particular disabled individual would otherwise face. It also allows account to be taken of the nature, size and available resource of the particular duty-bearer. For these reasons, Lawson and Liisberg have both argued that duties such as the EqA's anticipatory reasonable adjustment duty have important roles to play in disability equality law, whilst urging that care should be taken to limit uncertainty wherever practicable. ${ }^{74}$

One important way in which problems of uncertainty can be limited is by the provision of clear, detailed and influential guidance to which judges will have regard when determining questions of reasonableness. The EqA itself is silent on how questions of reasonableness should be determined but some guidance is provided by the statutory Code of Practice on Services and Public Functions. ${ }^{75}$ This notes that the question of whether steps are reasonable is an objective question for courts to decide ${ }^{76}$ and that it depends on all the circumstances of the case, including:

- the type of service being provided;

- the nature of the service provider and its size and resources; and

- the effect of the disability on the individual disabled person. ${ }^{77}$

It also suggests that factors likely to be relevant to assessments of whether an adjustment is reasonable include its effectiveness in overcoming the relevant disadvantage; its practicability, cost, disruptiveness; and the resources of the duty-bearer, and availability of financial or other assistance for making the adjustment. ${ }^{78}$

The purpose of the duty, according to the Code, is "to ensure that disabled people are not placed at a substantial disadvantage compared with non-disabled people when using a service". ${ }^{79}$ The Code also emphasises,

\footnotetext{
${ }_{72}^{72}$ See the discussion of this issue in Lawson, Disability and Equality Law in Britain, 285-86.

73 Pearson, "What's Worth Got to Do with It?"

${ }^{74}$ See e.g. Lawson, Disability and Equality Law in Britain, ch. 6.5; and Liisberg, "Accessibility of Services and Discrimination".

${ }^{75}$ EHRC Code, particularly ch. 7

76 Ibid., at [7.33].

${ }^{77}$ Ibid., at [7.29].

78 Ibid., at $[7.30]$

${ }^{79}$ Ibid., at [7.35].
} 
in line with case law, that the "policy of the Act is not a minimalist policy of simply ensuring that some access is available to disabled people; it is, so far as is reasonably practicable, to approximate the access enjoyed by disabled people to that enjoyed by the rest of the public". ${ }^{80}$

Despite such guidance, some uncertainty about whether particular adjustments are reasonable or not inevitably persists, as recognised by relevant parliamentary committees ${ }^{81}$ and by studies in fields such as healthcare, ${ }^{82}$ tertiary education, ${ }^{83}$ live entertainment ${ }^{84}$ and the justice system. ${ }^{85}$ This begs questions as to whether there is a need for additional measures generating greater clarity and certainty, albeit at the expense of losing some flexibility. One such measure might be rules or presumptions that certain types of steps should always or never be regarded as reasonable. Section 22(2)(a) of the EqA provides a means by which this might happen. It allows for the introduction of regulations specifying "circumstances in which it is, or in which it is not, reasonable for a person of a prescribed description to have to take steps of a prescribed description". Numerous calls for the introduction of such measures were made to the House of Lords Committee in 2015-16. These included calls for "explicit standards for the built environment and the delivery of services"; 86 regulations specifying that shops, restaurants and other service providers are obliged to admit assistance dogs; ${ }^{87}$ and legislation to clarify the meaning of "reasonable adjustments" in the context of deaf people using British Sign Language. ${ }^{88}$ The Committee, however, rejected such calls for fear that they might unhelpfully restrict the flexibility of the reasonable adjustment duty. ${ }^{89}$

The House of Lords Committee's reluctance to recommend regulations that would introduce greater certainty into the operation of the reasonable

${ }^{80}$ Ibid., at [7.4].

81 See notes 12-17 above and accompanying text.

82 See e.g. S. Read et al., "Disabled People's Experiences of Accessing Reasonable Adjustments in Hospitals: A Qualitative Study" (2018) 18 BMC Health Service Research, available at https:// bmchealthservres.biomedcentral.com/articles/10.1186/s12913-018-3757-7 (last accessed 8 April 2021), 2.

83 See e.g. H. Cameron et al., "Equality Law Obligations in Higher Education: Reasonable Adjustments under the Equality Act 2010 in Assessment of Students with Unseen Disabilities" (2019) 39 Legal Studies 204.

84 See e.g. S. Bunbury, "An Analysis of the Service Provider's Legal Duty to Make Reasonable Adjustments: The Little Mix Saga” (2020) 18 The Entertainment and Sports Law Journal 2.

85 See e.g. P. Swift et al., "What Happens When People with Learning Disabilities Need Advice about the Law?" (2013) Norah Fry Research Centre, available at https://legalservicesboard.org.uk/research/ reports/what-happens-when-people-with-learning-disabilities-need-advice-about-the-law (last accessed 8 April 2021); and EHRC, "Inclusive Justice: A System Designed for All" (2020), available at https://www.equalityhumanrights.com/en/publication-download/inclusive-justice-system-designed-all (last accessed 8 April 2021).

86 House of Lords Committee, "The Equality Act 2010", [210] referring to written evidence submitted by Portsmouth Disability Forum.

87 Ibid., at [210] referring to written evidence submitted by Guide Dogs for the Blind Association.

88 Ibid., at [211] referring to written evidence submitted by British Deaf Association.

89 Ibid., at [217]. 
adjustment duty is, we suggest, less persuasive in the context of the anticipatory reasonable adjustment duty than it is in the context of the reactive duty. For the latter, responsiveness to the particular circumstances of the individual disabled person in the specific case is critical. The emphasis of the former, however, is on duty-bearers taking reasonable steps to remove a disadvantage that would otherwise be encountered by broad groups of disabled people, rather than on responding to the particularities of the specific case in question. This emphasis on groups rather than individuals would seem to make it possible to supplement the wide-ranging flexible duty based on reasonableness with regulations that generate some degree of certainty - including by specifying steps that would always, never or generally be reasonable for certain types of duty-bearers to take. Examples might include situations in which it would always be reasonable for providers of public functions or services to offer communication in British Sign Language and situations in which it would always be reasonable for certain types of providers of public functions or services to permit access to assistance dogs.

This said, considerable care needs to be taken to ensure that any such regulations increase certainty in ways that make a positive contribution to disability equality and that implementing the requirements they impose is practicable for those to whom they apply - as well as being effectively monitored and enforced. The only regulations to have been issued to date on the question of reasonableness, the Equality Act 2010 (Disability) Regulations 2010 , demonstrate some of the problems that can attend the introduction of regulations. These regulations operate in reasonable adjustment disputes involving providers of services or public functions and focus on whether adjustments should be made to physical features. They effectively create a 10-year exemption from liability, specifying that for 10 years after the installation of the contested physical feature, any adjustments to it will not be regarded as reasonable - provided that it was installed "for the purpose of assisting people to have access to the building or ... facilities provided in the building" and in accordance with Part M (Access to and Use of Buildings) of the Building Regulations 2010.90 As the Women and Equalities Committee pointed out, although the scope of this exemption is relatively narrow, the fact that it is based on compliance with the now very outdated Part $\mathrm{M}$ standards is highly problematic. ${ }^{91}$ It thus provides an example of the unhelpful ossification that can occur when interpretations of "reasonableness" are linked to specific sets of technical standards - particularly when those standards are not regularly updated.

The fact that there are problems with the 2010 Regulations, however, is not a reason for rejecting the possibility that other, more carefully crafted,

\footnotetext{
${ }^{90}$ See in particular Equality Act 2010 (Disability) Regulations 2010, reg. 9 and para. 1 of the schedule.

91 Women and Equalities Committee, "Building for Equality", [134].
} 
regulations might play a useful role in reducing some of the uncertainty associated with the anticipatory reasonable adjustment duty. Consultation and involvement of disabled people's organisations and other stakeholders will obviously be key to the development of successful and effective regulations. ${ }^{92}$ Disability equality law in Norway provides a good example of a system in which such regulations play a key role - laying out accessibility standards and specifying that non-compliance with them constitutes unlawful discrimination..$^{93}$

We therefore argue that more attention should be given to the possibility of using section 22 of the EqA to introduce regulations about how "reasonable" should be interpreted. This would help to clarify expectations and give greater certainty to duty-bearers and disabled people alike. This may itself reduce the need for litigation. Where enforcement action is needed, however, the mechanism would be the same as for the enforcement of the anticipatory reasonable adjustment duty more generally. As discussed in Section $\mathrm{V}$ below, this enforcement mechanism is currently beset by a number of very serious problems. Unless and until these can be resolved, thought should be given to setting out relevant standards in new pieces of legislation (separate from the EqA) which establish simpler and cheaper enforcement mechanisms, not so heavily dependent on action by individual disabled claimants. This would also provide an important opportunity to expand the scope of what is regulated to include the sale or distribution of goods - an issue which currently falls outside the scope of the EqA.

A recent and interesting example of an approach which provides additional clarity to the operation of the anticipatory reasonable adjustment duty, without using section 22 regulations and which also introduces new awareness-raising, monitoring and enforcement mechanisms, is the Public Sector Bodies (Websites and Mobile Applications) (No. 2) Accessibility Regulations 2018. These regulations were introduced into UK law in order to ensure compliance with EU law. ${ }^{94}$ They specify that failure to meet relevant accessibility requirements (based on making websites and apps "perceivable, operable, understandable and robust") ${ }^{95}$ - or to provide information in alternative formats - should be treated as a breach of the EqA's reasonable adjustment duty. ${ }^{96}$ They give the role of enforcing these accessibility requirements to the EHRC. ${ }^{97}$ In addition, they require public sector bodies to publish "accessibility statements", which identify

\footnotetext{
92 A point stressed over a decade ago by Gooding and Casserley, "Open for All?", s. 4.1.

93 For further discussion, see e.g. Liisberg, "Accessibility of Services and Discrimination".

94 Directive (EU) 2016/2102 (OJ 2016 L 327 p.1) on the accessibility of the websites and mobile applications of public sector bodies.

95 Public Sector Bodies (Websites and Mobile Applications) Accessibility Regulations 2018, SI 2018/852, reg. 3. The harmonised standards mentioned in regulation 9, are set out in ETSI EN 301549 Accessibility Requirements for ICT Products and Services.

96 Ibid., reg. 12.

97 Ibid., reg. 11.
} 
and give reasons for any respects in which the website is not fully accessible, give details of how individuals can seek accessibility-related help from the website host and how they can notify them, and the relevant enforcement body of problems and non-compliance. ${ }^{98}$ The Cabinet Office is required to carry out regular compliance monitoring of public sector websites $^{99}$ and given responsibilities for enforcing accessibility statements. ${ }^{100}$ These regulations help give additional clarity and certainty to the reasonable adjustment duty in public sector cases. Their influence is also likely to extend, albeit indirectly, into anticipatory reasonable adjustment cases where the duty-bearer is a private sector body. The fact that they shift responsibility for compliance monitoring and enforcement away from disabled individuals is also potentially very significant. The long-term impact of these regulations, however, will depend on issues such as the ongoing commitment of the UK Government to this process after Brexit, the communication between the governmental compliance monitors and the EHRC enforcers, and the place of website-accessibility enforcement in the EHRC's strategy and resource allocation. ${ }^{101}$

In summary, while the concept of reasonableness gives the anticipatory reasonable adjustment duty valuable breadth and flexibility, we suggest that its operation would be enhanced by the additional certainty that would come from carefully crafted regulations or standards for specific types of steps or situations. Furthermore, as discussed above, ${ }^{102}$ increasing the prominence of relevant guidance by including it in a separate code of practice on reasonable adjustments would help disabled people and possibly also duty-bearers to locate, understand and use it.

\section{B. The Extent of Obligations to Take Reactive or Responsive Steps as Part of the Anticipatory Reasonable Adjustment Duty}

It is clear that the anticipatory reasonable adjustment duty has a strong proactive dimension and that, as explained in Section II above, it is owed to disabled people generally rather than a particular disabled person. As noted by Jackson M.R., this means that, when determining whether reasonable adjustments have been made, judges must have regard to the needs of the relevant group of disabled people (for instance, people who are deaf) and not solely the needs of the specific individual in question. ${ }^{103}$ It thus requires action in advance of a complaint or request by any particular

\footnotetext{
98 Ibid., reg. 8.

99 Ibid., reg. 10.

100 Ibid., reg. 14.

101 See further S. Lewthwaite and A. James, "Accessible at Last?: What Do New European Digital Accessibility Laws Mean for Disabled People in the UK?" (2020) 35 Disability \& Society 1360.

102 Section III(B) above.

103 Finnigan v Chief Constable of Northumbria Police [2013] EWCA Civ 1191, [2014] 1 W.L.R. 445, at [31].
} 
disabled individual. Despite this, section 21 of the EqA provides that it can be enforced only by an individual who has experienced a relevant substantial disadvantage.

The fact that the enforcement of the anticipatory duty is so firmly placed in the hands of particular individuals, who must themselves have been disadvantaged by the failure of a duty-bearer to make reasonable adjustments, suggests that the duty might include obligations to take steps to respond to the particular circumstances of the individual in question even though it may not have been possible for the duty-bearer to anticipate those circumstances. The EqA does not address this issue explicitly, however, and it is from this that the uncertainty about the extent to which the anticipatory duty includes obligations to make reactive or responsive adjustments springs. Nevertheless, it is clear that the CRPD's reactive or responsive reasonable accommodation duty extends to the provision of services and public functions. ${ }^{104}$ Accordingly, although there is a lack of clarity in the wording of the EqA, consistency with the CRPD demands an interpretation whereby the anticipatory duty includes a reactive dimension imposing duties to respond to the specific and unanticipated circumstances of the particular case. ${ }^{105}$

The anticipatory duty has been so interpreted in guidance issued by the EHRC. The statutory Code, for instance, includes the observation that

[o]nce a service provider has become aware of the requirements of a particular disabled person who uses or seeks to use its services, it might then be reasonable for the service provider to take a particular step to meet these requirements ... especially ... where a disabled person has pointed out the difficulty that they face in accessing services, or has suggested a reasonable solution to that difficulty. ${ }^{106}$

Beyond this, however, the Code offers little additional guidance on the reactive dimension of the anticipatory duty. Much fuller guidance on the matter is provided in non-statutory technical guidance. ${ }^{107}$

The fact that the anticipatory reasonable adjustment duty also contains obligations to make adjustments that are responsive, rather than anticipatory, suggests that referring to it as the "anticipatory" duty may itself be a cause of confusion - suggesting that there is no reactive element. Nevertheless, there has to date been little concern about whether the duty

104 See generally CRPD Committee, "General Comment No. 6".

105 For detailed analysis of situations in which judges may draw on the CRPD to interpret domestic legislation, see A. Lawson and L. Series, "The United Kingdom" in L. Waddington and A. Lawson (eds.), The UN Convention on the Rights of Persons with Disabilities in Practice: A Comparative Analysis of the Role of Courts (Oxford 2018).

106 EHRC Code, [7.26].

107 EHRC, "Equality Act 2010: Technical Guidance on Further and Higher Education" (2014), available at https://www.equalityhumanrights.com/en/publication-download/ equality-act-2010-technical-guidance-further-and-higher-education (last accessed 8 April 2021), [7.62][7.68]. 
includes a responsive dimension - the general assumption seeming to be that it does. ${ }^{108}$ This may in part be because there is greater familiarity with the way in which the reasonable adjustment duty operates in employment cases, and an assumption that similar principles apply in contexts of services and public functions.

Accordingly, EHRC guidance goes some way to addressing the uncertainty associated with the EqA's lack of clarity about the existence and nature of the responsive elements of the anticipatory duty. The effectiveness of this guidance depends on the clarity and detail of the guidance and on levels of awareness of its existence. In the statutory Code, the level of detail is minimal.

\section{Enforcement Problems}

The enforcement of the anticipatory reasonable adjustment duty has been hampered by a range of factors. For current purposes, these have been grouped into two broad categories, discussed in Sections $\mathrm{V}(\mathrm{A})$ and $\mathrm{V}(\mathrm{B})$, respectively.

Section $\mathrm{V}(\mathrm{A})$ is concerned with the enforcement of the EqA and its anticipatory reasonable adjustment duty in the context of services and public functions. EqA cases on services and public functions are heard in the first instance by county courts in England and Wales and sheriff courts in Scotland. ${ }^{109}$ Discrimination claims relating to employment, on the other hand, are heard by employment tribunals. Contrasts between these two types of forums have prompted three main types of concerns about the enforcement of non-employment cases - costs, lack of judicial expertise and inadequate reporting of judgments. After addressing each of these issues, attention will turn to enforcement problems specific to the anticipatory duty.

Section V(B) is concerned with the enforcement of the EqA more broadly - not simply in relation to the anticipatory duty or services and public functions. Any reflection on the enforcement of the anticipatory reasonable adjustment duty would be incomplete without some acknowledgement of these more general enforcement problems. In order to maintain focus, however, discussion will necessarily be brief.

\section{A. Enforcement Issues with Particular Relevance to the Anticipatory} Reasonable Adjustment Duty and Services and Public Functions Cases

\section{Costs of bringing cases}

The cost of bringing non-employment discrimination cases, including for breach of the anticipatory duty, is one of the biggest barriers in the way

\footnotetext{
108 See e.g. Cameron et al., "Equality Law Obligations in Higher Education".

109 Equality Act 2010, s. 114(1).
} 
of such litigation. ${ }^{110}$ In 2019, the EHRC indicated that it paid an average of about $£ 28,000$ on supporting each individual discrimination case. ${ }^{111}$ This figure includes costs such as legal advice, representation and court fees. The potential deterrent impact of the costs of litigation may be gauged by the dramatic fall in the number of cases taken to the employment tribunal when fees were payable; ${ }^{12}$ and the fact that, after such fees were abolished, the number of cases nearly doubled. ${ }^{113}$

The cost of bringing a case for breach of the anticipatory duty depends on the value of the claim, the track to which it is allocated, and whether it goes to trial. ${ }^{114}$ This complexity makes it difficult to predict the cost of bringing a case, which may itself have a deterrent effect on potential claimants. Also relevant is the fact that, because damages awarded to successful claimants in services cases are relatively low, they may well be less than the cost of bringing the case. ${ }^{115}$

The imposition of fees for employment tribunal cases ${ }^{116}$ was ruled to be unlawful by the Supreme Court in R. (on the application of UNISON) $v$ Lord Chancellor. ${ }^{117}$ This ruling drew heavily on principles of access to justice under EU law and the common law right of access to a court. This common law right was subsequently used, but without success, to challenge the problems faced by discrimination claimants in non-employment cases in $R$. (on the application of Leighton) $v$ the Lord Chancellor. ${ }^{118}$ Fees thus remain payable for EqA cases in county and sheriff courts. Although the CRPD Committee has recommended that disabled people bringing discrimination cases should not have to pay court fees, ${ }^{119}$ arguments based on the CRPD in Leighton fell on hard ground. ${ }^{120}$

The Legal Aid, Sentencing and Punishment of Offenders Act 2012 (LASPO) has exacerbated problems for discrimination claimants in county and sheriff courts in a number of ways. First, courts can no longer require

110 Women and Equalities Committee, "Enforcing the Equality Act 2010", [193].

111 Ibid., at [193].

${ }^{112} R$ (on the application of UNISON) $v$ Lord Chancellor [2017] UKSC 51, [2017] 3 W.L.R. 409, at [38][39], referencing Ministry of Justice, "Review of the Introduction of Fees in the Employment Tribunals: Consultation on Proposals for Reform" (31 January 2017), Cm 9373, [105].

113 From around 4,200 claims in the second quarter of 2014-15, to 8,173 claims in the third quarter of 201718: Ministry of Justice, "Tribunals and Gender Recognition Certificate Statistics Quarterly: October to December 2017" (2018), available at https:/www.gov.uk/government/statistics/tribunals-and-genderrecognition-certificate-statistics-quarterly-october-to-december-2017 (last accessed 8 April 2021), 6-7.

114 Sheriff Court Fees Order 2018, SI 2018/81, Sched. 2; Civil Proceedings Fees Order 2008, SI 2008/1053, Sched. 1.

115 These points were made on behalf of the claimant in $R$. (on the application of Leighton) $v$ the Lord Chancellor [2020] EWHC 336, [2020] A.C.D. 50, at [37]; see also Section V(A)(4) below.

116 Such fees were introduced by the Employment Tribunals and the Employment Appeal Tribunal Fees Order 2013.

117 [2017] UKSC 51, [2017] 3 W.L.R. 409.

118 [2020] EWHC 336. Cavanagh J. (e.g. at [148], [151], [161]) distinguished the Unison case from the one before him.

119 CRPD Committee, "Concluding Observations on the United Kingdom" (CRPD/C/UK/CO/1, 2017), [32 (c)], [33(c)].

120 Leighton v Lord Chancellor [2020] EWHC 336, at [216]-[221]. 
an unsuccessful defendant to pay the "success fee" to which a claimant's lawyers may be entitled under a conditional fee agreement, ${ }^{121}$ giving lawyers less security that they will be paid and thus making it more difficult for claimants to find lawyers willing to represent them. Second, courts can no longer require unsuccessful defendants to pay the cost of claimants' after-the-event (ATE) insurance premiums ${ }^{122}$ - insurance, often prohibitively expensive, against the risk of having to pay the defendant's costs. Hence, while the defendant may be ordered to pay a successful claimant's costs, considerable financial risk remains with the claimant in respect of liability for success fees and ATE premiums. If unsuccessful, claimants of course risk not just having to pay their own costs, but also being ordered to pay those of the defendant. ${ }^{123}$ This risk is particularly acute for claimants in non-employment discrimination cases because in county and sheriff courts, unlike employment tribunals, such cost orders are not confined to exceptional circumstances involving unreasonable behaviour. ${ }^{124}$ Further, the sums involved may be high - large enough "to wipe out the cost of somebody's home". ${ }^{125}$

While LASPO addressed these problems for personal injury cases by introducing a system of qualified one-way cost-shifting (QOCS), it did not extend this safeguard to discrimination cases. Despite repeated recommendations that QOCS be extended to discrimination cases, ${ }^{126}$ and a 2019 review of LASPO, ${ }^{127}$ this has not yet happened. The Government's failure to take this action was challenged in the Leighton case. ${ }^{128}$ Although Cavanagh J. dismissed the case because the Government was still actively considering whether to extend QOCS in this way, he indicated that ongoing governmental inactivity might ultimately provide grounds for judicial review. ${ }^{129}$ The primary reason given by the Government for its delay was the lack of significant statistical evidence on the impact of LASPO, and the unavailability of QOCS, on discrimination cases. ${ }^{130}$ Nevertheless, it seems clear from what Cavanagh J. describes as "primarily anecdotal"131

\footnotetext{
121 Courts and Legal Services Act 1990, s. 58A(6) (amended by LASPO, s. 44(4)).

122 Ibid., s. 58C(1) (inserted by LASPO, s. 46(1)).

123 Women and Equalities Committee, "Enforcing the Equality Act 2010", [193], [208].

124 Ibid., at [209].

125 N. Whitingham, cited ibid., at [209].

126 House of Lords Committee, "The Equality Act 2010", [395]-[402]; Women and Equalities Committee, "Enforcing the Equality Act 2010", [210]-[212]; and EHRC, "Response of the Equality and Human Rights Commission to the Post-implementation Review of Part 2 of the Legal Aid, Sentencing and Punishment of Offenders Act 2012" (2018), available at https://www.equalityhumanrights.com/sites/ default/files/consultation-response-on-post-implementation-review-of-part-2-laspo-7-september-2018. pdf (last accessed 8 April 2021).

127 Ministry of Justice, "Post-implementation Review of Part 2 of the Legal Aid, Sentencing and Punishment of Offenders Act 2012 (LASPO): Civil Litigation Funding and Costs" (2019), CP 38, available at https://assets.publishing.service.gov.uk/government/uploads/system/uploads/attachment_data/ file/777039/post-implementation-review-of-part-2-of-laspo.pdf (last accessed 8 April 2021).

128 Leighton $v$ Lord Chancellor [2020] EWHC 336.

129 Ibid., at [65].

130 See e.g. the argument reported ibid., at [46].

131 Ibid., at [129]; see also at [211].
} 
evidence that the impact has been severe. Such evidence has come from disabled people's organisations ${ }^{132}$ and also from lawyers. The following is a powerful example of the latter:

I note from my own experience that whilst I undertook many disability discrimination claims in the county court in the years up to 2013, after that point they fell off a cliff. Yet the problems that disabled people face have not gone away: instead disabled people deprived of a means of defraying their potential costs liabilities, face a locked and bolted door into court, precluding them from using litigation to get redress. ${ }^{133}$

\section{Lack of judicial experience and expertise}

Compared with judges in employment tribunals, judges in county and sheriff courts are likely to have less familiarity with, and expertise in, equality law concepts including reasonable adjustments. ${ }^{134}$ They tend to be legal generalists and, because relatively few EqA cases come before them, ${ }^{135}$ do not have the opportunity to develop significant expertise in the area. Accordingly, in 2020, the Law Commission recommended a system of "flexible deployment", whereby employment tribunal judges with equality law experience could, in appropriate circumstances, be deployed to hear EqA cases in county courts. ${ }^{136}$ While this recommendation is to be welcomed in general terms, it is likely to be of very limited help in relation to the anticipatory reasonable adjustment duty. This is because expertise in employment discrimination will entail familiarity with the reactive reasonable adjustment duty. The anticipatory duty, however, is not relevant in the employment context and is therefore not part of the EqA to which judges will routinely be exposed in employment tribunals. Alongside this initiative, we therefore urge that specific judicial training on the anticipatory reasonable adjustment duty is essential.

Concerns about lack of equality expertise in county and sheriff courts, as well as concern about the costs of such proceedings, ${ }^{137}$ have prompted calls for the setting up of low cost specialist bodies to replace or supplement them. Thus, prior to the EqA, the House of Commons Work and Pensions Committee recommended the introduction of a specialist equality

132 See e.g. Inclusion London's “Disability Justice Project”, available at https://www.disabilityjustice.org. uk/ (last accessed 2 January 2021).

133 A. Hogan, "Disability Discrimination and QOCS: Andrew Hogan's Blog on Costs and Litigation Funding" (2020), available at https://costsbarrister.co.uk/access-to-justice/disability-discrimination-andqocs/ (last accessed 26 May 2021).

134 Law Commission, "Employment Law Hearing Structures: Report" (2020) HC 308, available at "https:// www.gov.uk/government/publications/employment-law-hearing-structures-report" (last accessed 8 April 2021), [3.7], [3.83].

135 No statistics are published but in Leighton v Lord Chancellor [2020] EWHC 336, at [38], the claimant's solicitor estimated that there were approximately 100 such discrimination cases each year.

136 Law Commission, "Employment Law Hearing Structures", [3.95]-[3.101].

137 See the discussion of cost-related concerns in Section V(A)(1) above. 
tribunal to hear all EqA cases. ${ }^{138}$ No such tribunal has been introduced however, and the Law Commission has acknowledged the strength of counterarguments based on the potential negative impact of moving equality cases and associated expertise out of mainstream courts and tribunals. ${ }^{139}$ Importantly though, without training and other initiatives to build equality law expertise across the judicial mainstream, such counterarguments lose much of their power.

Another idea, mooted by the House of Lords Committee, was the creation of a disability ombudsman. While there was some support for such an approach, the Committee was persuaded by arguments that the multiplicity of existing ombudsmen was creating confusion and that a better approach would be to embed equality expertise within existing bodies and services. ${ }^{140}$

\section{Limited reporting of judgments}

Unlike employment tribunal judgments, county and sheriff court judgments are not routinely published. This makes it difficult to gauge the number, nature and focus of non-employment cases. As the Women and Equalities Committee has pointed out, this absence of data makes it impossible for the EHRC to identify emerging patterns and problem issues and thus weakens the evidence base from which it can draw to inform its enforcement activities. ${ }^{141}$ Another example of the problems caused by a lack of relevant data, explained in Section $\mathrm{V}(\mathrm{A})(1)$ above, is that the impact of LASPO, and the unavailability of QOCS, on non-employment discrimination cases is unclear. The Government's reliance on this lack of data as a reason for delaying action intended to mitigate the obvious financial deterrents to bringing such cases is so unfair on claimants, and so antithetical to the aims of embedding equality in services and public functions, as to be perverse.

The problems associated with lack of reporting of county and sheriff court judgments do not fall evenly across the EqA. They have particular significance for those elements, including the anticipatory reasonable adjustment duty, which operate only in non-employment contexts and thus fall outside the jurisdiction of employment tribunals (the judgments of which are reported). Reporting county and sheriff court cases, a practice strongly recommended by the Women and Equalities

${ }^{138}$ House of Commons Work and Pensions Committee, "The Equality Bill: How Disability Equality Fits Within a Single Equality Act" (2009) HC 158-I, available at https://publications.parliament.uk/pa/ cm200809/cmselect/cmworpen/158/158i.pdf (last accessed 11 April 2021), [265]; see also Lawson, Disability and Equality Law in Britain, 280-81.

139 Law Commission, "Employment Law Hearing Structures, [3.8], [3.11].

140 House of Lords Committee, "The Equality Act 2010", [453]-[462].

141 Women and Equalities Committee, "Enforcing the Equality Act 2010", [217]-[219]; see also EHRC, "Access to Legal Aid for Discrimination Cases" (2019), available at https://www.equalityhumanrights. com/en/publication-download/access-legal-aid-discrimination-cases (last accessed 11 April 2021), 35. 
Committee, ${ }^{142}$ is a "simple change that can enable individual litigation to achieve wider change". ${ }^{143}$

\section{Under-use of injunctive remedies for breach of the anticipatory duty}

As explained above, ${ }^{144}$ the anticipatory reasonable adjustment duty is proactive, requiring duty-bearers to monitor constantly how they deliver their services and public functions and take reasonable steps to make them disability-inclusive. Its focus is on systemic change and the removal of barriers that disadvantage disabled people beyond the particular claimant. As stressed in argument in Leighton, anticipatory reasonable adjustment duties "are directed towards achieving equal access to service provision for all disabled persons" and therefore

unlike discrimination claims in other fields, the main objective is not usually to obtain damages or some other remedy for an individual in relation to an incident that happened in the past, but, rather, the main objective is to make things better in the future for the whole cohort of persons who share the claimant's protected characteristic, and who are disadvantaged by the impediment in issue. ${ }^{145}$

It might therefore be expected that, where courts find the duty has been breached, injunctive relief would regularly be ordered. The importance of such forward-looking remedies in cases of systemic discrimination has been stressed in guidance from the CRPD Committee. ${ }^{146}$ On the basis of this guidance, the fact that a disabled person can seek injunctive (or indeed any other) relief for breach of the EqA anticipatory duty only if they have actually experienced a disadvantage is highly problematic as it means that there is no way of using the duty to halt the installation of exclusionary systems or infrastructures at an early stage of development.

County and sheriff courts, unlike employment tribunals, do have the power to grant injunctions (interdicts or specific implements in Scotland). ${ }^{147}$ A notable example of an anticipatory reasonable adjustment case in which this occurred is Royal Bank of Scotland $v$ Allen, ${ }^{148}$ where the Court of Appeal upheld an order that the defendant should install a platform lift in order to enable the claimant, and other wheelchair users, to access its services. More recently, a similar injunction was awarded against a restaurant in the unreported case of Lawson $v$ Abbey Wharf Restaurant. ${ }^{149}$

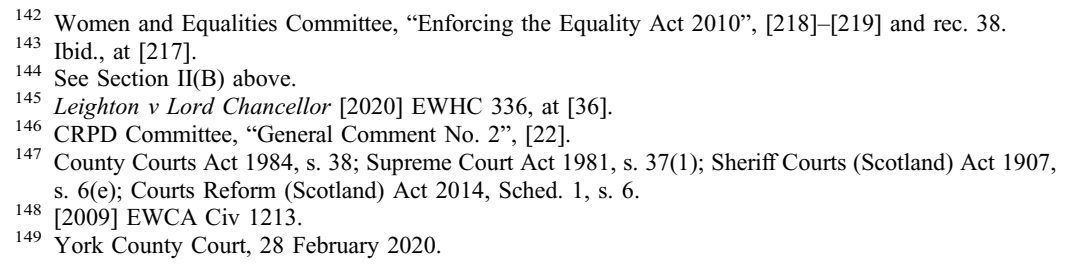


The fact that county and sheriff court judgments are not reported makes it difficult to ascertain exactly how many successful anticipatory reasonable adjustment cases result in injunctive relief. Nevertheless, it is clear that it is a rarity in reported cases and it seems unlikely that the situation will be very different in unreported cases. This contrasts markedly with the US approach where the standard remedy for breach of the reasonable modification duty is injunctive relief and it is not possible to award damages to individual claimants. ${ }^{150}$

The House of Lords Committee suggested that one likely cause of the limited use of injunctive relief in EqA cases was the fact that disabled claimants and their legal representatives were often unaware that they could request such relief. ${ }^{151}$ For this reason, it called for relevant court documents and guidance to highlight the power of county and sheriff courts to award injunctive relief in EqA cases. ${ }^{152}$ Such guidance should also make it clear that requests for injunctive relief will generally be difficult to negotiate without legal representation and that expert evidence will also often be needed - both of which will push up litigation costs.

More injunctive relief in anticipatory reasonable adjustment cases would enhance the social impact of litigation brought by individual disabled claimants. It should not, however, be regarded as a panacea. Ensuring that injunctions are in fact carried out may present challenges for courts. ${ }^{153}$ Injunctions are also limited in that they must relate specifically to the particular complaint, with the result that they are unlikely to require general measures, such as disability equality training. ${ }^{154}$ Nor do county or sheriff courts have the power to issue recommendations for wider organisational or sectoral change - a situation which the Women and Equalities Committee has rightly urged should be changed. ${ }^{155}$

\section{B. Enforcement Issues Relating to Equality Act Discrimination Claims More Broadly}

\section{Limited access to legal aid and advice}

Despite the fact that LASPO did not withdraw legal aid funding from discrimination cases, its reforms have made it more difficult for victims of all types of discrimination, including breaches of the anticipatory reasonable

\footnotetext{
150 Americans with Disabilities Act 1990, 42 USC s. 12188(a)(2). Under 42 USC s. 12188(b), however, fines may be imposed in cases brought by the Attorney-General. See generally Blanck, Disability Law and Policy, ch. 12.8 .

151 House of Lords Committee, "The Equality Act 2010", [423].

152 Ibid.

153 See further D. Barrett, "The Regulatory Space of Equality and Human Rights in Britain: The Role of the Equality and Human Rights Commission" (2019) 39 Legal Studies 247, 252-53.

154 This point was made by the DRC in its Initial Submission to the Discrimination Law Review (London 2006), [2.3.2].

155 Women and Equalities Committee, "Enforcing the Equality Act 2010", [225].
} 
adjustment duty, to access legal aid and advice. ${ }^{156} \mathrm{~A}$ particularly significant barrier for many disabled claimants was LASPO's introduction of a mandatory telephone gateway for individuals wishing to access legal aid. ${ }^{157}$ The difficulties posed by this communication method for people with a range of impairments (including hearing impairments, mental health conditions and learning difficulties), exacerbated by failures to make effective reasonable adjustments to the system, led the EHRC to conclude that the gateway operated in a manner amounting to disability discrimination contrary to the EqA's anticipatory reasonable adjustment duty. ${ }^{158}$ These problems have now been largely addressed because, in May 2020, the Government removed the obligatory nature of the gateway. ${ }^{159}$

LASPO also caused a dramatic reduction in the availability of legal advice on issues such as discrimination. This came about, in part, due to the closure of many organisations providing legal advice because of LASPO's severe cuts to the legal aid budget ${ }^{160}$ and its restrictions on conditional fee agreements and ATE insurance policies. ${ }^{161}$ Consequently, as Douglas Johnson reported to the House of Lords Committee: "[t]here are precious few firms of solicitors in the country that will go anywhere near a discrimination case. ... It is simply not cost effective for most firms of solicitors to take that risk from a business sense."162 It is therefore unsurprising that the enforcement of EqA rights, including its anticipatory duty, currently depends very heavily on the deep commitment to disability equality, as well as the business innovation and agility, of a small number of law firms. The precarity inherent in such an approach is self-evident and, as will be suggested below, is mitigated only partially by the support available from the EHRC and other regulators.

\section{Under-use of enforcement mechanisms not dependent on individual claimants}

The enforcement problems addressed thus far all concern enforcement of EqA rights by individual claimants. They highlight ways in which engaging in discrimination litigation is unduly difficult or in which the impact of that

\footnotetext{
156 See e.g. EHRC, "Access to Legal Aid for Discrimination Cases"; and Joint Committee on Human Rights, "Enforcing Human Rights" (2018) HC 669, available at https://publications.parliament.uk/pa/ jt201719/jtselect/jtrights/669/669.pdf (last accessed 11 April 2021), [33].

157 Introduced under LASPO, s. 2, and set out in the Civil Legal Aid (Procedure) Regulations 2012, pt. 2 (revoking the Civil Legal Aid (Procedure) (Amendment) Regulations 2020, reg. 5).

158 EHRC, "Access to Legal Aid for Discrimination Cases", 7-8; EHRC, "Human Rights Review 2012: How Fair is Britain? An Assessment of How Well Public Authorities Protect Human Rights" (2012), available at https://www.equalityhumanrights.com/en/publication-download/human-rights-review-2012 (last accessed 11 April 2021), 255; see also Joint Committee on Human Rights, "Enforcing Human Rights", [49]-[51].

159 Ministry of Justice, Legal Support Action Plan: The Way Ahead, 7 February 2019, CP 40, 15.

160 See e.g. House of Lords Committee, "The Equality Act 2010", [392]; and Women and Equalities Committee, "Enforcing the Equality Act 2010", [198].

161 Notes 122-125 above and accompanying text.

162 House of Lords Committee, "The Equality Act 2010", [394].
} 
litigation is unhelpfully restrictive. Tackling these problems is important. Even were they all to be successfully addressed, however, there would still be a pressing need to look beyond enforcement by individual claimants toward more systemic and strategic approaches. The Women and Equalities Committee has expressed profound concern about the extent to which enforcement of the EqA has to date relied on enforcement by individuals. In its words, "an approach that relies on individual disabled people bringing a challenge each and every time they encounter a disabling barrier is neither morally nor practically sustainable"; 163 and we need "a fundamental shift in the way that enforcement of the Equality Act is thought about and applied". ${ }^{164}$

Any shift away from the current heavy dependence on individual enforcement entails a strengthening of alternative approaches, amongst which the powers of the EHRC are key. Duties imposed on the Commission by the Equality Act 2006 include the enforcement of the EqA. ${ }^{165}$ To discharge this duty, it is given power to assist a person who is or may become a party in an EqA case by, for example, providing the costs of legal advice and representation. ${ }^{166}$ Important though this power is, it still ultimately depends on enforcement by individuals. In addition, however, the Commission is given a range of enforcement powers to challenge unlawful acts (such as breaches of the anticipatory reasonable adjustment duty) independently of litigation brought by individual claimants. ${ }^{167}$ The Commission has been criticised for making insufficient use of these unique enforcement powers ${ }^{168}$ and for focusing too heavily on supporting individual litigation. ${ }^{169}$ Persuaded by these concerns, the Women and Equalities Committee has observed that "the burden of enforcement has been borne by individuals, even where the EHRC has become involved"170 and that "this piece by piece approach is insufficient in the face of ... systemic and routine discrimination". ${ }^{171}$

While there is scope for the EHRC to increase its use of the full range of its enforcement powers, even given the dramatic shrinking of its resources mentioned above, ${ }^{172}$ there are clearly limits on what it can be expected to

163 Women and Equalities Committee, "Building for Equality", [12].

164 Women and Equalities Committee, "Enforcing the Equality Act 2010", [23]

165 Equality Act 2006, s. 8(1)(c), (d) and (e), respectively.

166 Ibid., s. 28.

167 Ibid., ss. 20-27.

168 See e.g. House of Lords Committee, "The Equality Act 2010", [126]-[127]; HM Government, "Tailored Review of the Equality and Human Rights Commission" (2018), available at https://assets. publishing.service.gov.uk/government/uploads/system/uploads/attachment_data/file/756905/

EHRC-Tailored-Review-Nov18.pdf (last accessed 11 April 2021), 4; and Women and Equalities Committee, "Enforcing the Equality Act 2010", [43]-[45]; Joint Committee on Human Rights, "Enforcing Human Rights", [124]-[126].

169 Women and Equalities Committee, "Enforcing the Equality Act 2010", [32]-[37].

170 Ibid., at [34].

171 Ibid., at [37].

172 See above note 67 and accompanying text. See also Joint Committee on Human Rights, "Enforcing Human Rights", [131]-[132]. 
achieve. These expectations could be raised were there to be increases in its resourcing and powers. However, this would not address the need for what the Women and Equalities Committee has described as a "fundamental shift in the burden of enforcement, with mainstream enforcement bodies taking up the bulk of the work". ${ }^{173}$ To achieve this, it recommended that each government department should be required to ensure that all of its sector-specific enforcement bodies (such as regulators, inspectorates and ombud offices) are using their powers to bring about compliance with the EqA. ${ }^{174}$ The EHRC should not only support such bodies in carrying out this role, as argued by Barrett, ${ }^{175}$ but should actively challenge them through enforcement action for any failure to discharge it adequately. ${ }^{176}$

\section{CONCLUSION}

The anticipatory reasonable adjustment duty remains the principal legal tool in the UK for embedding disability equality and inclusion into services and public functions. The combination of factors discussed above, however, has operated to reduce its profile and create a perfect storm against its effectiveness and impact. Without action, its influence is likely to diminish further. The price for this will be borne primarily by disabled people who will continue to be disadvantaged or excluded from services and public functions which should be equally available to all. It will, to a lesser extent, also fall on others who would benefit from more accessible and disability-inclusive services and public functions - for example, people with temporary injuries, older people, and parents or carers with pushchairs and buggies.

The action required is not, in our view, the complete abolition and replacement of the duty as proposed by Pearson. ${ }^{177}$ Its dependence on notions of reasonableness, while imposing some limits and entailing a degree of uncertainty and unpredictability, has the merit of flexibility and responsiveness to the specific circumstances of a particular case. Further, the fact that the duty is qualified by the limits of reasonableness means that it is possible for the duty to have its current broad material scope applying as it does across the range of services offered to the public and functions discharged by public authorities. These are important benefits which do not need to be completely sacrificed in efforts to tackle the current problems.

While the anticipatory duty should remain part of the solution, it is in urgent need of reform. The most pressing of the problems it currently

\footnotetext{
173 Women and Equalities Committee, "Enforcing the Equality Act 2010", [123].

174 Ibid., at [121].

175 Barrett, "The Regulatory Space of Equality and Human Rights in Britain", 261-62.

176 Women and Equalities Committee, "Enforcing the Equality Act 2010", [126]-[127].

177 Note 73 above and accompanying text.
} 
faces are those concerning enforcement. Helpful initiatives are afoot to give sector regulators more responsibility for monitoring EqA compliance, into which it is imperative that the anticipatory nature of the reasonable adjustment duty for services and public functions is fully integrated. It seems unlikely, however, that these will result in new quick, affordable and effective mechanisms for making complaints and seeking remedial action. The primary complaint mechanism remains individual litigation in the county and sheriff courts and, for the anticipatory reasonable adjustment duty, this system is badly broken for the reasons discussed in Section $\mathrm{V}$ above. It would improve, at least to some extent, were measures taken to extend QOCS to discrimination cases; require more reporting of discrimination case law; introduce better judicial training in this area; and enhance operational guidance on injunctive relief and make such relief available without having to wait for a disabled person to experience actual disadvantage.

The anticipatory duty also needs to be made more visible. This could be achieved by amendments to the EqA which could, for example, introduce a new section $20 \mathrm{~A}$ specifically on the anticipatory reasonable adjustment duty. The duty would also benefit from greater certainty and clarity. In terms of its general effect, it would be helpful to have greater clarity and recognition of its reactive or responsive dimensions. More important, however, is the clarity that would come from statutory presumptions about what would or would not be reasonable in particular types of setting or circumstance - a measure that could be achieved through the regulation-making power conferred by section 22 of the EqA.

Useful though section 22 regulations would be in providing clear expectations about what embedding disability equality in services and public functions means, the enforcement of these expectations would be subject to all the problems associated with enforcing the anticipatory reasonable adjustment duty identified in Section V above. It is, of course, to be hoped that action will be taken to address and mitigate these problems but it seems likely that many will remain. It is therefore important, as argued above, ${ }^{178}$ that thought be given to the introduction of new ways of requiring services and public functions to be disability-inclusive - new measures that would supplement and sit alongside the EqA anticipatory duty, but with distinct monitoring, compliance and enforcement mechanisms. An obvious focus for such new requirements and mechanisms is accessibility - in light of recent initiatives in other parts of the world, such as the European Accessibility Act $2019^{179}$ and the Accessible Canada Act 2018. ${ }^{180}$ Such a venture could impose requirements on

\footnotetext{
178 Notes 94-101 above and accompanying text.

179 Directive (EU) No 2019/882 (OJ 2019 L 151 p.70).

180 S.C. 2019 , ch. 10.
} 
manufacturers and distributors of goods as well as services and thereby address what remains a problematic gap in the coverage of the EqA.

To conclude, the anticipatory reasonable adjustment duty has important work to do and, despite some successes, is failing to live up to its early promise. Much the same might be said of the EqA generally, but the blockages to success discussed above place the anticipatory duty at particular risk. Only if these are unblocked will the duty have a chance to fulfil its potential to tackle the barriers which in turn block access to services and public functions for disabled people. 